\title{
Chemical Oxidation for Oil Separation from Oilfield Produced Water under UV Irradiation Using Titanium Dioxide as a Nano-Photocatalyst by Batch and Continuous Techniques
}

\author{
Ali A. Hassan $\mathbb{D D}^{1}$ and Khalid M. Mousa Al-zobai ${ }^{2}$ \\ ${ }^{1}$ Chemical Eng. Dep., Al-Muthanna University, Samawah, Iraq \\ ${ }^{2}$ Chemical Eng. Dep., Al-Nahrain University, Baghdad, Iraq \\ Correspondence should be addressed to Ali A. Hassan; alkhafajia31@gmail.com
}

Received 18 November 2018; Revised 27 March 2019; Accepted 19 May 2019; Published 24 June 2019

Academic Editor: Raghunath V. Chaudhari

Copyright (c) 2019 Ali A. Hassan and Khalid M. Mousa Al-zobai. This is an open access article distributed under the Creative Commons Attribution License, which permits unrestricted use, distribution, and reproduction in any medium, provided the original work is properly cited.

\begin{abstract}
This research describes the photocatalytic design for oil removal from produced water. It involves batch and continuous processes. The photocatalytic degradation of oil has been conducted in glass reactors. The effects of nano- $\mathrm{TiO}_{2}$ concentration, the number of lamps, and the time of radiation were studied in the batch system, while in the continuous treatment, the number of lamps, the direction of light radiation, and the time of processes were studied. The results showed that all the oil was removed in the batch system and the maximum percentage of oil removal was $71 \%$ in the continuous system.
\end{abstract}

\section{Introduction}

The regular processes of oil and gas manufacturing include huge quantity of injected water to ease the oil recovery. This water is transported to the surface lengthways with organic compounds, salt, and additional solutes and is commonly identified as "produced water" $[1,2]$. The conformation of produced water (PW) is multifaceted and can include numerous compounds that differ in concentration. Dissolved oil, aromatic hydrocarbons, and alkyl phenols (AP) are of specific environmental anxiety [3]. Because oilfield wastes cause environmental pollutions, handling is essential before removal. Treatment of these wastes will possibly result in enhanced oil/water separation, oil recovery, water recycle, defense of downstream amenities, and environmental license compliance [4]. The treatment of PW is definitely significant as a result of lawmaking and environmental concerns. All lengthways accompanying stringent environmental regulations need diverse wastewater treatment from oil and gas manufacturers before release and before injection into reservoirs to decrease creation damage [5]. Produced water treatment is being industrialized to decrease the quantity of the produced water to satisfactory levels [6]. Conservative treatment instituted has been less active for removing some pollutants from produced water [7, 8]. Numerous techniques are obtainable for the separation of organic content from produced water, counting a variability of coagulation [9-11], adsorption [12], biological separation [13], and membrane separation [14] . However, none of these treatment approaches is active to treat the produced water. Extra treatment stage is optional, which is known as the advanced oxidation processes (AOPs) $[15,16]$. AOPs can totally destroy the organic contaminants to carbon dioxide and water. Amongst the many AOPs, heterogeneous photocatalytic squalor has been originated to be an extremely active treatment skill. $\mathrm{TiO}_{2}, \mathrm{CdS}$, or $\mathrm{ZnO}$ are likely catalysts in the advanced oxidation process. Nanodimensional $\mathrm{TiO}_{2}$ has an extremely exact surface area, which indorses wellorganized charge separation and charge tricking of ions on the $\mathrm{TiO}_{2}$ surfaces. The nanosized $\mathrm{TiO}_{2}$ demonstrations augmented oxidative power with opacity of the aqueous phase associated with the bulk-sized $\mathrm{TiO}_{2}$ [17-20]. Several researchers deliberate the elimination of organic pollutants by using AOPs: photo-fenton oxidation [21] and solar 
photo-catalysts $\mathrm{TiO}_{2}$ and $\mathrm{ZnO}$ [22], and other researchers used AOPs for other purposes such as removal of phenolics [9], mineralization [23], treatment of gasoline-contaminated waters [24], and removal of olive mill effluents $[25,26]$. The principal aim of this study was to remove oil from produced water of Al-Ahdab Oilfield, Iraq, by using photocatalytic oxidation processes: first, to find the optimum value of $\mathrm{TiO}_{2}$ and irradiation time for batch technical; second, to study the effects of UV intensity, effect of light direction, flow rate, and irradiation time on photocatalytic processes. It is worthy to state that the removal of oil means that all the organic pollutes will be degraded.

\section{Materials and Methods}

2.1. Materials. Titanium dioxide powder with a particle size of less than $30 \mathrm{~nm}$ was used. Sodium hydroxide and $\mathrm{H}_{2} \mathrm{SO}_{4}$ (98\% purity) were used to adjust the $\mathrm{pH}$. Carbon tetrachloride was used to extract oil from the produced water. All of the materials were used without additional purification.

2.2. Produced Water. The produced water sample was obtained from Al-Ahdab Oilfield in Iraq. The produced water used in these experiments was brought from the oilfield exposed to the atmosphere and then kept in an environment similar to their native habitat that contains oxygen until the treatment process is beneficial. The characterization of produced water is given in Table 1.

2.3. UV/TiO $\mathrm{O}_{2}$ Batch Reactor. The photocatalyst was charged into $250 \mathrm{~mL}$ of produced water solution. The solution was irradiated under UV hollow equipped with eight UV tubes (each of $18 \mathrm{~W}$ consuming a wavelength of $365 \mathrm{~nm}$ ). A magnetic stirrer was used to mix the solution in the container. Prior to irradiation, the $\mathrm{pH}$ of the solutions was measured using a WTW pH-720 digital pH meter. Titanium dioxide rummage-sale in the various concentrations $(25,35$, 50 , and $150 \mathrm{ppm}$ ), room temperature, $\mathrm{pH}=6.5$, and $1.5 \mathrm{~h}$ irradiation time.

2.4. Setup of Continuous Flow Reactor. The overall arrangement of the experimental setup is presented in Figure 1. The hollow (6) was made completely of wood with black color with an effective volume of $75 \times 75 \times 85 \mathrm{~cm}^{3}$, containing the photocatalytic glass reactor with a dimension of $50 \times 50 \times 20 \mathrm{~cm}$ as shown in Figure 2. A feed tank (1) of 251 volume was used to prepare the solution. The solution was supplied by using a water pump (2). To measure the flow rate, a calibrated flow meter (5) was used.

2.5. Continuous Photocatalytic Processes. Photocatalytic oxidation of oil was achieved by use of a suspension of required quantity of photocatalyst powder into 25 liter of PW. A solution containing $59.55 \mathrm{ppm}$ of oil content was used. $\mathrm{pH}$ was adjusted to $\mathrm{pH}=6.5$ by addition of diluted $\mathrm{H}_{2} \mathrm{SO}_{4}$ solution into the feed tank (1). The required amount of $\mathrm{TiO}_{2}(25 \mathrm{mg} / \mathrm{l})$ was added to the feed tank (1). Circulation
TABLE 1: Constituents of oilfield produced water used in this study.

\begin{tabular}{lc}
\hline Constituent & Concentration $\mathrm{mg} \cdot \mathrm{l}^{-1}$ \\
\hline Oil & 59.55 \\
$\mathrm{pH}$ & 6.86 \\
TDS & 137800 \\
TSS & 21 \\
Calcium & 7840 \\
Magnesium & 2352 \\
$\mathrm{HCO}_{3}$ & 263 \\
Dissolved oxygen content & 0.07 \\
Manganese & 3 \\
Zinc & 1 \\
Chrome & 0.2 \\
Iron & 0.35 \\
Sulphate & 3763 \\
Chloride & 107192 \\
Nickel & 0.2 \\
\hline
\end{tabular}

was allowed for 10 minutes when the valve (4) was locked to get a uniform solution. The pump (2) was switched on, and the solution was allowed to flow from the feed tank (1) through the pump to the photocatalytic reactor (6). The UV light source was switched on in the photocatalytic reactor (6). Samples were taken via the valve (7). All experiments were conducted at room temperature, and the flow rates (20, 35 , and $50 \mathrm{ml} / \mathrm{min}$ ) were controlled with a flow meter. Samples were taken for analysis using the UV spectrometer to find the percentage of oil removal in produced water using the following equation:

$$
\eta=\frac{A_{\mathrm{o}}-A_{t}}{A_{\mathrm{o}}} \times 100 \%,
$$

where $\eta$ is the percentage of oil removal, $A_{\mathrm{o}}$ is the initial concentration of oil in PW (mg.oil/l), and $A_{t}$ is the concentration of oil in PW at any time (mg.oil/l). The concentration of oil was found by the following procedure: $0.25 \mathrm{~g}$ of sodium chloride was added to $50 \mathrm{ml} \mathrm{PW}$ in the separating funnel. Five milliliters of carbon tetrachloride was added and shaken for $3 \mathrm{~min}$. After $25 \mathrm{~min}$, once the solution separated into two distinct layers, the inferior (organic) layer was occupied for the absorbance measurement, and from the calibration curve, the oil concentration was obtained. The wavelength of oil in produced water is 312 micrometer. It is worthy to state that the amount of oxygen consumed to chemically oxidize organic (COD) was measured before and after the treatments and it was found to be 2000 and $63 \mathrm{ppm}$, respectively. The UV spectrometer was used to measure the oil concentration due to its availability in the laboratory.

\section{Results and Discussion}

\subsection{Batch Photocatalytic Processes}

3.1.1. Photo-Oxidation Performance. One of the purposes of this work was to assess the knowledge on photocatalysis. Figure 3 illustrates the oil percentage removal at different titanium dioxide concentrations. From this figure, it can be seen that the oil percentage removal is increased as the concentration of $\mathrm{TiO}_{2}$ increased from $91 \%$ at $25 \mathrm{ppm}$ of $\mathrm{TiO}_{2}$ 


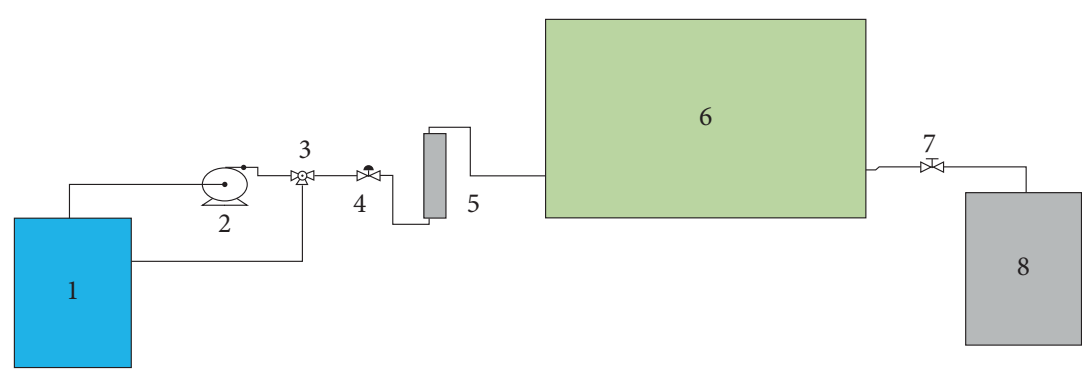

Figure 1: A laboratory scale setup of the photocatalytic system. (1) Feed tank (produced water), (2) water pump, (3) divider, (4) valve, (5) flow meter, (6) chamber containing the photocatalytic reactor, (7) sample extraction valve, and (8) container tank ("produced water" treatment).

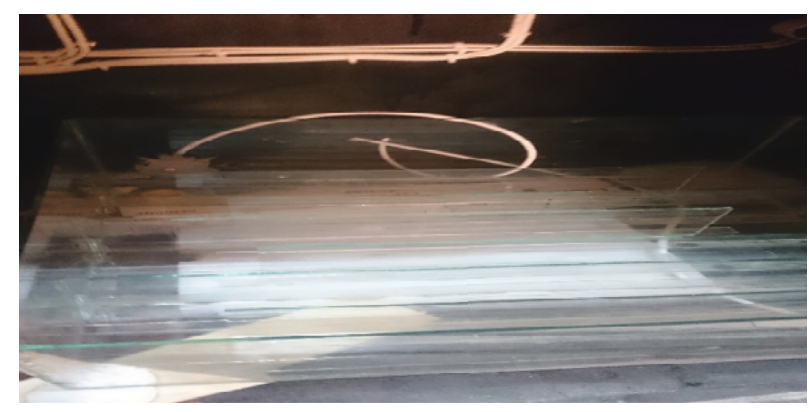

Figure 2: Photocatalytic reactor.

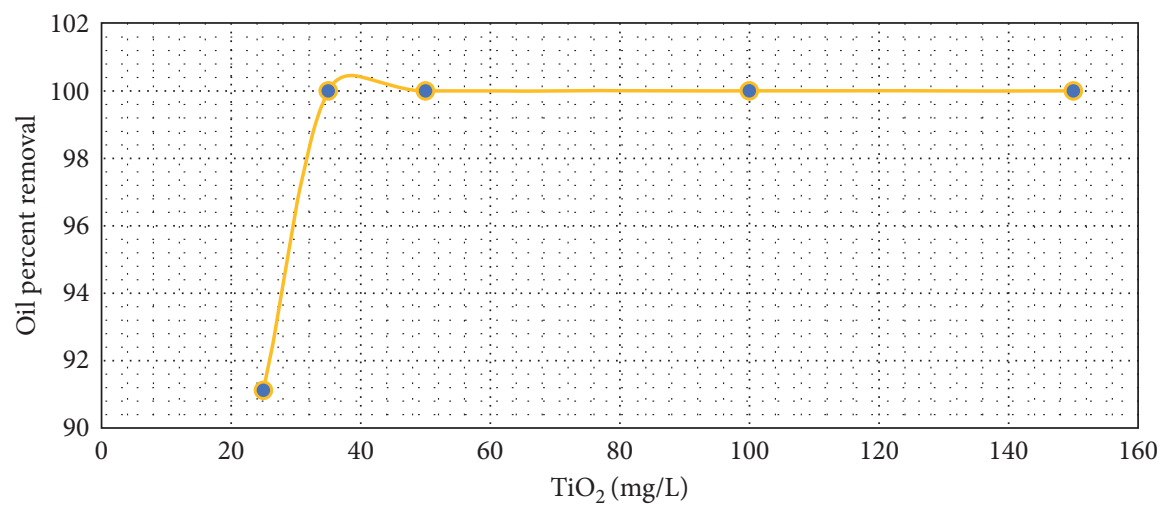

Figure 3: Effect of $\mathrm{TiO}_{2}$ on oil percent removal $(\mathrm{pH}=6.5$; time $=90 \mathrm{~min}$; room temperature $)$.

to the maximum removal efficiency of $100 \%$ at $35 \mathrm{ppm}$ of titanium dioxide. The greatest quantity of titanium dioxide has to be determined with the intention of evading the use of the needless catalyst in excess and also to confirm the whole absorption of the irradiating photons so that an effective photo remediation is achieved. The increase in $\mathrm{TiO}_{2}$ concentration leads to increase in the surface area of catalyst, so the removal of the organic pollutants will increase $[27,28]$.

3.1.2. Effect of Irradiation Time. The effects of irradiation time on a photocatalytic reactor were examined using batch experiments. Figure 4 shows the results. The oil percentage removal increased with the increase in irradiation time. The best irradiation time was 1.5 hour; this agrees with Horng et al.'s result [29]. The photocatalytic treatment time needs to be as little as to reduce electricity consumption, which signifies around $60 \%$ of the whole operative cost by means of electric light sources. However, if the immovable pretreatment time is also short, the intermediates that are residual in the solution might be motionless and structurally alike to early biorecalcitrant composites and, consequently, non-biodegradable [21].

3.2. Continuous Photocatalytic Processes. The photocatalytic scheme was studied using the continuous process. The UV radiation, direction of light radiation, flow rate, and irradiation time were studied. Intended for each assessment of the system, the discrete factor was wide ranging, while the others remain constant. The photocatalytic degradation competence of the organization was tested under an individual set of conditions. The volume of the reactor was selected in order to get a suitable time of the process. 


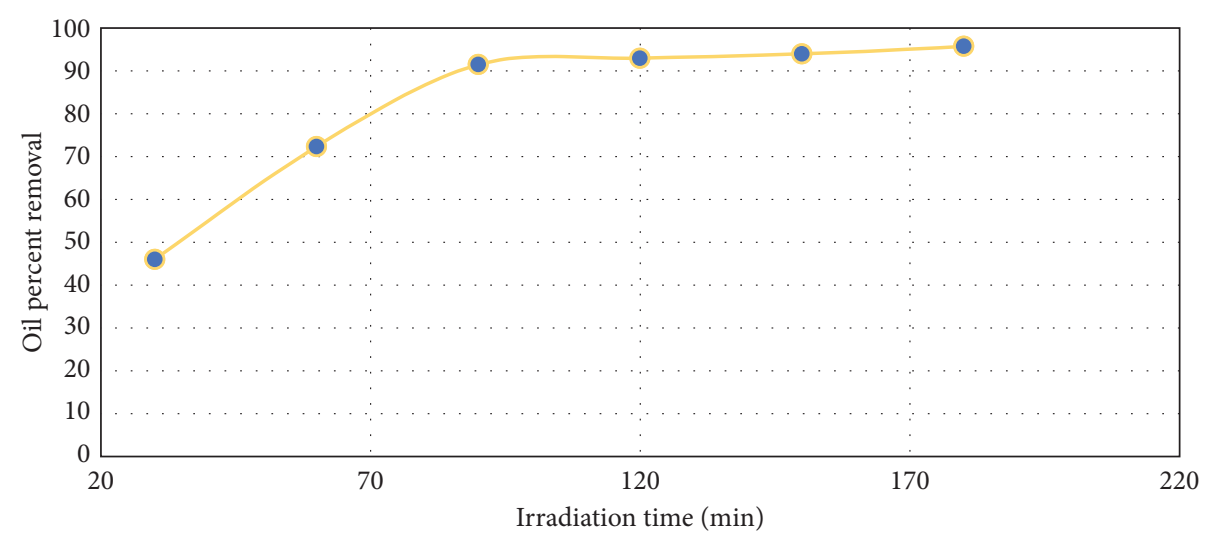

FIGURE 4: Effect of irradiation time on oil removal (titanium dioxide $=25 \mathrm{mg} / \mathrm{L} ; \mathrm{pH}=6.5$; room temperature).

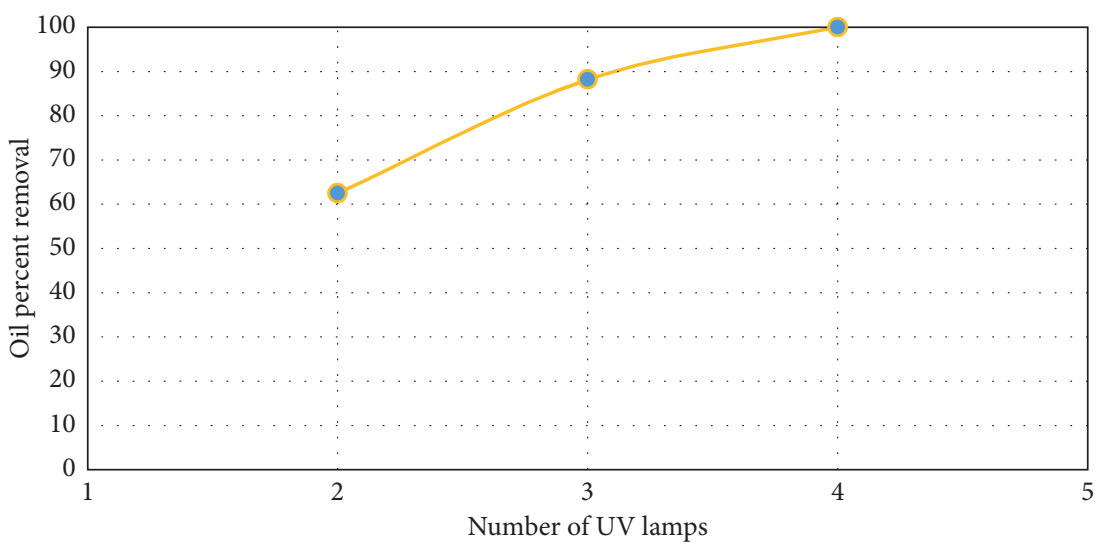

FIGURE 5: Effect of the number of UV lamps on oil percent removal.

3.2.1. Effect of UV Radiation. To investigate the UV radiation on the photoreactor, three experiments were conducted at three different average UV intensities. The effect of UV intensity on the photocatalytic process was studied by changing the number of UV lamps (2, 3, and 4$)$, while the other conditions were constant $(59.55 \mathrm{mg} / \mathrm{l}$ initial oil concentration with a $\mathrm{pH}$ value equal to $6.5, \mathrm{TiO}_{2}=25 \mathrm{mg} / \mathrm{l}$, $60 \mathrm{~min}$, flow rate $=20 \mathrm{ml} / \mathrm{min}$, and temperature was maintained through these experiments). Figure 5 illustrates the effect of the number of lamps on the oil elimination efficiency for PW. It is apparent that the number of supplementary UV lamps led to increase the removal efficiency due to increase in the free radicals. The experimental results using $4 \mathrm{UV}$ lamps are found to be adequate for $100 \%$ oil elimination of produced water. It is clear that the UV power tested in the current study was efficient. This is consistent with the results of Muruganandham and Swaminathan [30].

3.2.2. Effect of Light Radiation. A series of experiments were conducted at different light directions and at different flow rates $(20-50 \mathrm{ml} / \mathrm{min})$. The results indicated a decrease in the degradaion of the oil contents when using the top direction of the light compared with the side direction especially at a low flow rate. The effect of the light direction is clear in the 35 and $50 \mathrm{ml} / \mathrm{min}$ flow rate particularly in the high flow rate as shown in Figures 6 and 7. The behavior indicates that the surface area of contact of the side light is lower than that of the top light. Therefore, the light direction had a substantial effect on the rate of degradation. The top light direction increases the generation rate of free radical more than the side light direction. These explanations are in agreement with those obtained by Haji et al. [31].

3.2.3. Effect of Flow Rate. The flow rate is one of the significant factors for investigating the rate of oil percentage elimination from PW solution flowing through the photocatalytic reactor. The oil removal of produced water had been investigated by varying the flow rate of produced water solution from 20 to $50 \mathrm{ml} / \mathrm{min}$. Figures 8 and 9 show that the $20 \mathrm{ml} / \mathrm{min}$ flow rate of produced water gives the maximum oil removal. In consequence of higher flow rate, the irradiation time between organic content in produced water and catalyst surface was reduced. As shown in Figure 8, the removal of oil gradually reduced to reach about $84 \%$ in the top and $79 \%$ in the side light direction. Low degradation with increasing the produced water flow rate indicates the effect of time for $\mathrm{TiO}_{2}$ to degrade the pollutants. This finding was in agreement with the results of Monteiro et al. [32]. This 


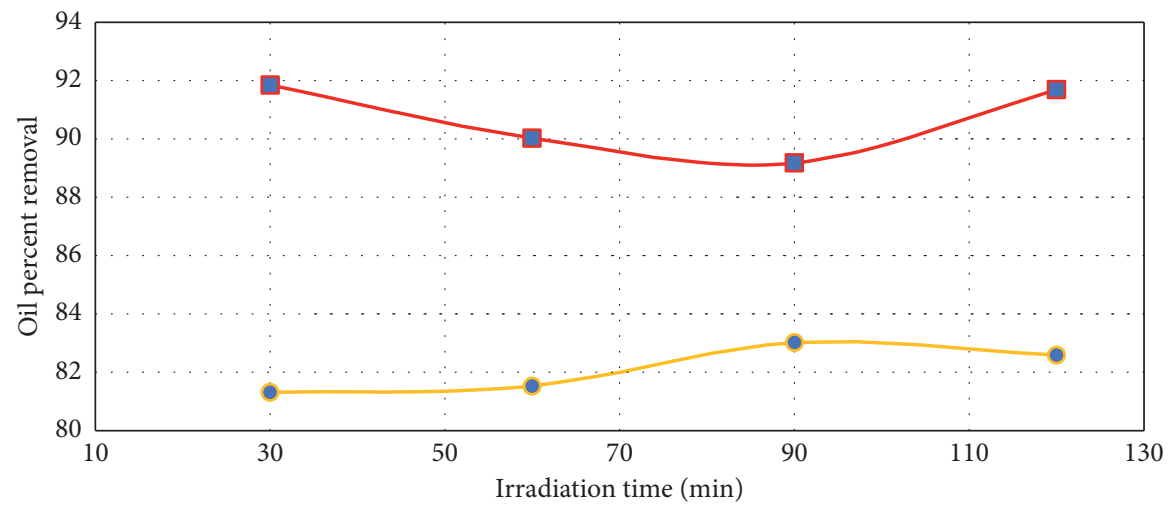

Top

- Side

Figure 6: Effect of light direction on oil percent removal: flow rate $35 \mathrm{ml} / \mathrm{min}$.

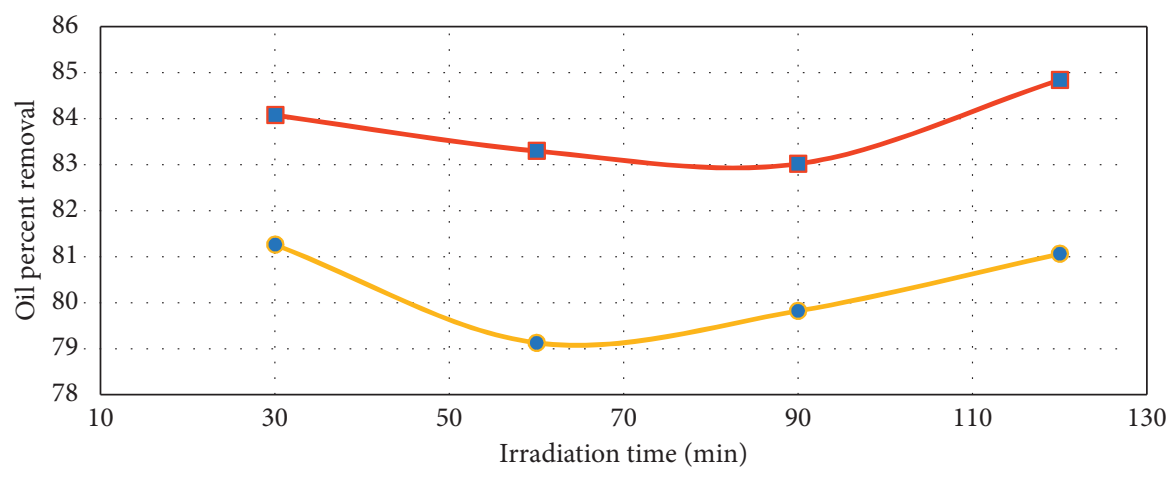

- Top

- Side

FIgURE 7: Effect of light direction on oil percent removal: flow rate $50 \mathrm{ml} / \mathrm{min}$.

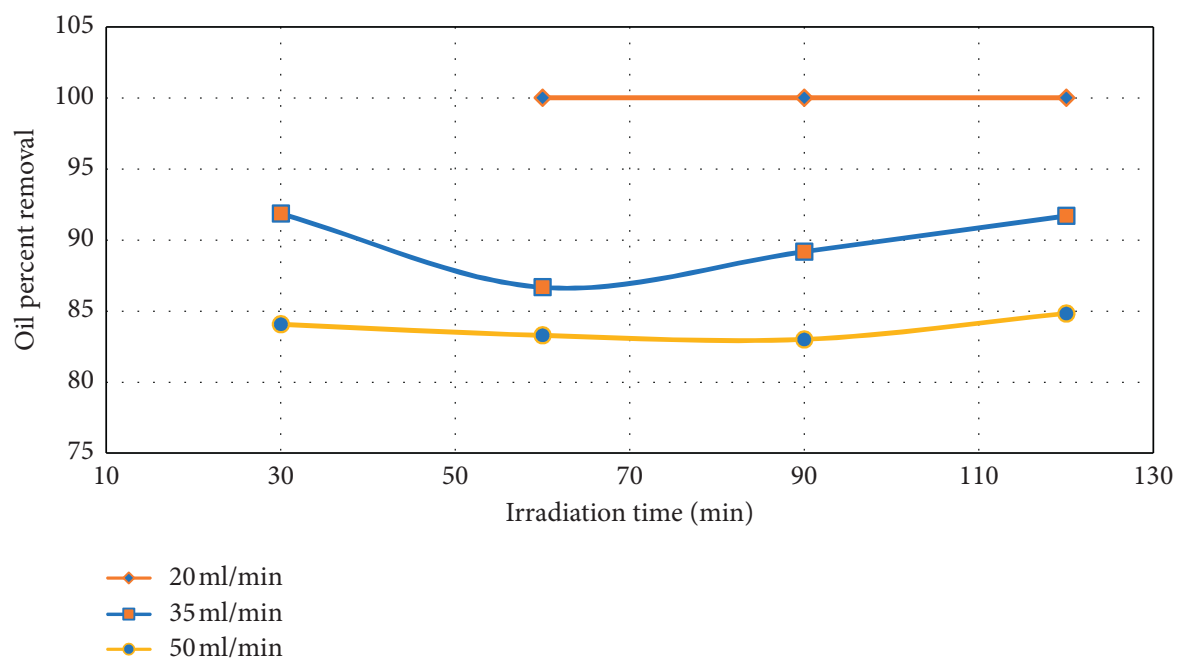

FIGURE 8: Effect of flow rate on oil percent removal (titanium dioxide $=25 \mathrm{mg} / \mathrm{L} ; \mathrm{pH}=6.5$; room temperature; 4 UV lamps in the top light direction).

can be explained by the fact that the residence time is reduced; the contaminant cannot be oxidized because of the decrease of the residence time which is not edequate for $\mathrm{TiO}_{2}$ to degrade the pollutant. Figures 8 and 9 indicate that extended residence time improves degradation rate effectively. This is a consequence of the fact that the adsorption rate of 


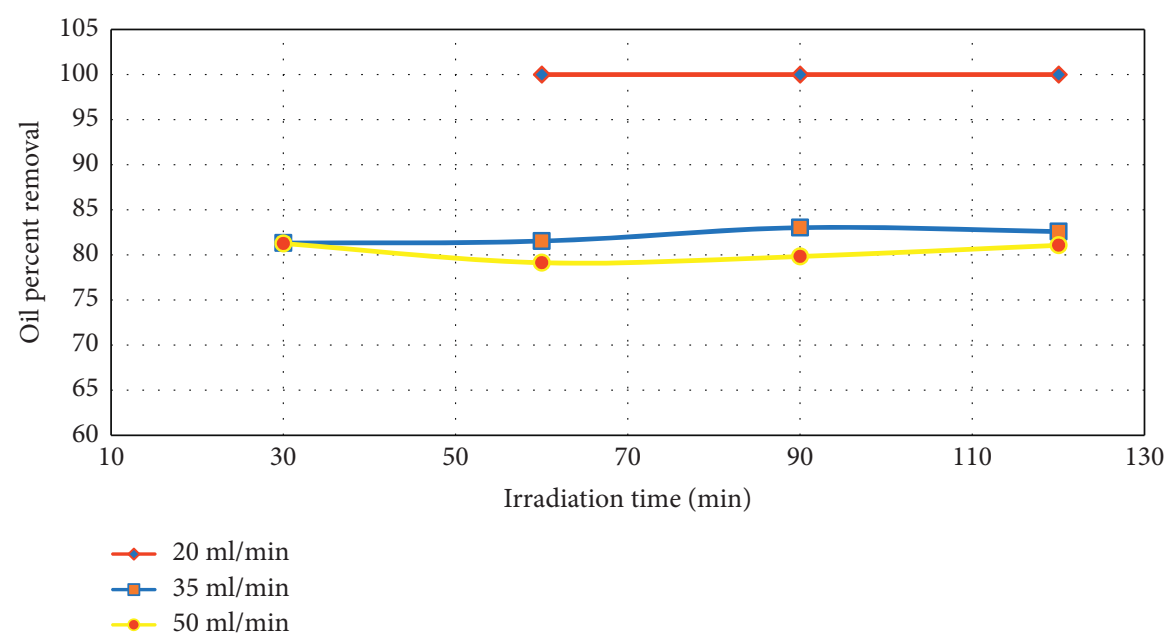

FIGURE 9: Effect of flow rate on oil percent removal (titanium dioxide $=25 \mathrm{mg} / \mathrm{L} ; \mathrm{pH}=6.5$; room temperature; 4 UV lamps in the side light direction).

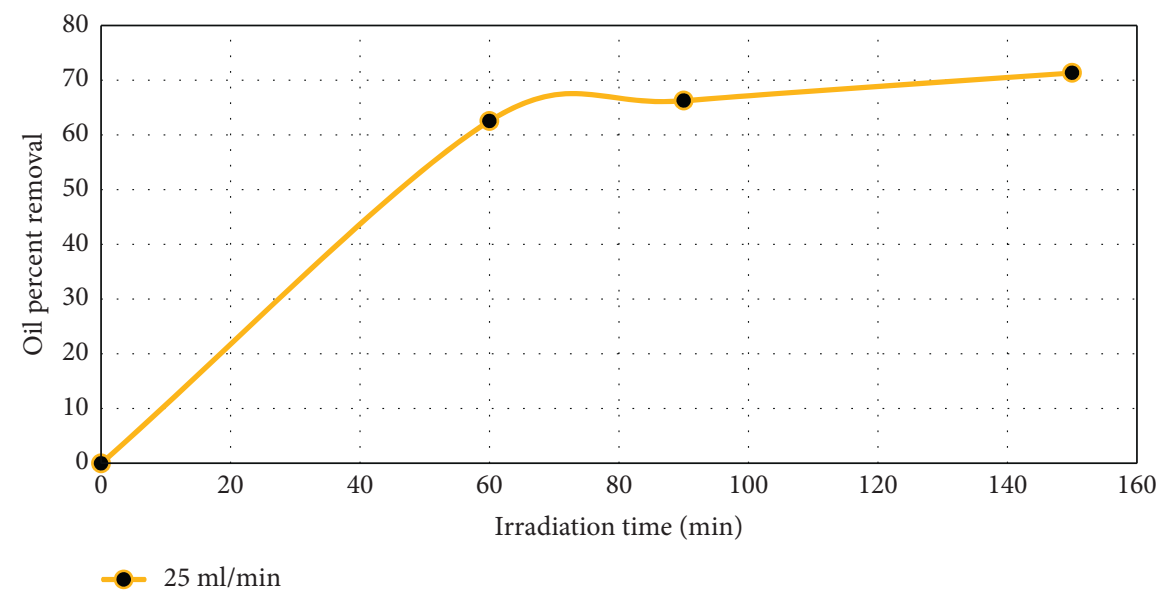

FIGURE 10: Effect of irradiation time on percent oil removal.

oil molecule on the catalyst upsurges the active surface area, and thus the reaction rate can be enhanced. It was shown experimentally that flow rate and concentration are inversely associated. The maximum oil removal efficiency for produced water was $100 \%$ at $20 \mathrm{ml} / \mathrm{min}$ using $4 \mathrm{UV}$ lamps in the top and side light directions.

3.2.4. Effects of Irradiation Time on Continuous Process. The irradiation time of the PW in the continuous photoreactor depends mainly on the flow rate and volume of the reactor. The effects of irradiation time were studied under the following conditions: $59.55 \mathrm{ppm}$ initial concentration of oil content in produced water, $\mathrm{pH}=6.5$, room temperature, and $\mathrm{TiO}_{2}=25 \mathrm{mg} / \mathrm{L}$. Figure 10 shows the results; the initial degradation rate is higher that will possibly be owing to more interaction between photocatalyst surface and produced water. The oil elimination efficiency of $62.5 \%$ was attained in $1 \mathrm{~h}$ when the retention time was augmented by the cumulative volume of the photoreactor at $1.5 \mathrm{~h}$. The removal effectiveness was increased to $66 \%$. After treatment time increased to $150 \mathrm{~min}$, the degradation level of the oil was significantly stable at $71 \%$ of oil removal efficiency. The consequences obtainable above are in accordance with the published findings [32, 33].

\section{Conclusions}

This work investigates the degradation of oil content from produced water by heterogeneous photocatalytic oxidation using nano- $\mathrm{TiO}_{2}$ by batch and continuous treatments. The photocatalytic degradation of oil content has been implemented in the glass reactor. The effects of $\mathrm{TiO}_{2}$ concentration, the number of lamps, and the time of radiation were studied in the batch system, and all the oil was removed. In continuous treatment, the number of lamps, light radiation, and time of the process were studied and the maximum oil percentage removal was $71 \%$.

\section{Data Availability}

The data used to support the findings of this study are included within the article. 


\section{Conflicts of Interest}

The authors declare that they have no conflicts of interest.

\section{Acknowledgments}

This study was performed at Al-Nahrian University, Iraq. The authors gratefully acknowledge the outstanding support provided by the technicians of the workshop in the College of Engineering.

\section{References}

[1] J. Xu, N. M. Srivatsa Bettahalli, S. Chisca et al., "Polyoxadiazole hollow fibers for produced water treatment by direct contact membrane distillation," Desalination, vol. 432, pp. 32-39, 2018.

[2] S. Jiménez, M. M. Micó, M. Arnaldos et al., "Integrated processes for produced water polishing: enhanced flotation/ sedimentation combined with advanced oxidation processes," Chemosphere, vol. 168, pp. 309-317, 2017.

[3] T. Bakke, J. Klungsøyr, and S. Sanni, "Environmental impacts of produced water and drilling waste discharges from the Norwegian offshore petroleum industry," Marine Environmental Research, vol. 92, pp. 154-169, 2013.

[4] K. Okiel, M. El-Sayed, and M. Y. El-Kady, "Treatment of oilwater emulsions by adsorption onto activated carbon, bentonite and deposited carbon," Egyptian Journal of Petroleum, vol. 20, no. 2, pp. 9-15, 2011.

[5] M. Fathy, M. El-Sayed, M. Ramzi, and O. H. Abdelraheem, "Adsorption separation of condensate oil from produced water using ACTF prepared of oil palm leaves by batch and fixed bed techniques," Egyptian Journal of Petroleum, vol. 27, no. 3, pp. 319-326, 2017.

[6] S. Shokrollahzadeh, F. Golmohammad, N. Naseri, H. Shokouhi, and M. Arman-mehr, "Chemical oxidation for removal of hydrocarbons from gas-field produced water," Procedia Engineering, vol. 42, pp. 942-947, 2012.

[7] J. R. Alvarez-Corena, J. A. Bergendahl, and F. L. Hart, "Advanced oxidation of five contaminants in water by UV/ $\mathrm{TiO}_{2}$ : reaction kinetics and byproducts identification," Journal of Environmental Management, vol. 181, pp. 544-551, 2016.

[8] L. Karimi, S. Zohoori, and M. E. Yazdanshenas, "Photocatalytic degradation of azo dyes in aqueous solutions under UV irradiation using nano-strontium titanate as the nanophotocatalyst," Journal of Saudi Chemical Society, vol. 18, no. 5, pp. 581-588, 2014.

[9] E. Hernández-Francisco, J. Peral, and L. M. Blanco-Jerez, "Removal of phenolic compounds from oil refinery wastewater by electrocoagulation and Fenton/photo-Fenton processes," Journal of Water Process Engineering, vol. 19, pp. 96-100, 2017.

[10] Y. O. Fouad, "Separation of cottonseed oil from oil-water emulsions using electrocoagulation technique," Alexandria Engineering Journal, vol. 53, no. 1, pp. 199-204, 2014.

[11] K. M. Mousa and A. A. Al-Hasan, "Oilfield produced water treatment by coagulation/flocculation processes," in Proceedings of the Second Conference of Post Graduate Researches (CPGR'2017), Baghdad, Iraq, October 2017.

[12] G. A. El-Din, A. A. Amer, G. Malsh, and M. Hussein, "Study on the use of banana peels for oil spill removal," Alexandria Engineering Journal, vol. 57, no. 3, pp. 2061-2068, 2017.

[13] Q. Li, C. Kang, and C. Zhang, "Waste water produced from an oilfield and continuous treatment with an oil-degrading bacterium," Process Biochemistry, vol. 40, no. 2, pp. 873877, 2005.

[14] M. Coto, S. C. Troughton, J. Duan, R. V. Kumar, and T. W. Clyne, "Development and assessment of photo-catalytic membranes for water purification using solar radiation," Applied Surface Science, vol. 433, pp. 101-107, 2018.

[15] J. M. Poyatos, M. M. Muñio, M. C. Almecija, J. C. Torres, E. Hontoria, and F. Osorio, "Advanced oxidation processes for wastewater treatment: state of the art," Water, Air, and Soil Pollution, vol. 205, no. 1-4, pp. 187-204, 2010.

[16] J. J. Rueda-Márquez, M. Sillanpää, P. Pocostales, A. Acevedo, and M. A. Manzano, "Post-treatment of biologically treated wastewater containing organic contaminants using a sequence of $\mathrm{H}_{2} \mathrm{O}_{2}$ based advanced oxidation processes: photolysis and catalytic wet oxidation," Water Research, vol. 71, pp. 85-96, 2015.

[17] J. Saien and H. Nejati, "Enhanced photocatalytic degradation of pollutants in petroleum refinery wastewater under mild conditions," Journal of Hazardous Materials, vol. 148, no. 1-2, pp. 491-495, 2007.

[18] H. Benhebal, M. Chaib, T. Salmon et al., "Photocatalytic degradation of phenol and benzoic acid using zinc oxide powders prepared by the sol-gel process," Alexandria Engineering Journal, vol. 52, no. 3, pp. 517-523, 2013.

[19] S.-Y. Lee and S.-J. Park, " $\mathrm{TiO}_{2}$ photocatalyst for water treatment applications," Journal of Industrial and Engineering Chemistry, vol. 19, no. 6, pp. 1761-1769, 2013.

[20] B. H. Diya'uddeen, W. M. A. W. Daud, and A. R. A. Aziz, "Treatment technologies for petroleum refinery effluents: a review," Process Safety and Environmental Protection, vol. 89, no. 2, pp. 95-105, 2011.

[21] E. E. Ebrahiem, M. N. Al-Maghrabi, and A. R. Mobarki, "Removal of organic pollutants from industrial wastewater by applying photo-Fenton oxidation technology," Arabian Journal of Chemistry, vol. 10, pp. S1674-S1679, 2017.

[22] D. A. D. A. Aljuboury, P. Palaniandy, H. B. A. Aziz, and S. Feroz, "Treatment of petroleum wastewater using combination of solar photo-two catalyst $\mathrm{TiO}_{2}$ and photo-Fenton process," Journal of Environmental Chemical Engineering, vol. 3, no. 2, pp. 1117-1124, 2015.

[23] A. A. Aziz and W. M. A. W. Daud, "Oxidative mineralisation of petroleum refinery effluent using Fenton-like process," Chemical Engineering Research and Design, vol. 90, no. 2, pp. 298-307, 2012.

[24] E. R. L. Tiburtius, P. Peralta-Zamora, and A. Emmel, "Treatment of gasoline-contaminated waters by advanced oxidation processes," Journal of Hazardous Materials, vol. 126, no. 1-3, pp. 86-90, 2005.

[25] P. C. Papaphilippou, C. Yiannapas, M. Politi et al., "Sequential coagulation-flocculation, solvent extraction and photo-fenton oxidation for the valorization and treatment of olive mill effluent," Chemical Engineering Journal, vol. 224, pp. 82-88, 2013.

[26] E. Chatzisymeon, S. Foteinis, D. Mantzavinos, and T. Tsoutsos, "Life cycle assessment of advanced oxidation processes for olive mill wastewater treatment," Journal of Cleaner Production, vol. 54, pp. 229-234, 2013.

[27] M. Yasmina, K. Mourad, S. H. Mohammed, and C. Khaoula, "Treatment heterogeneous photocatalysis; factors influencing the photocatalytic degradation by $\mathrm{TiO}_{2}$," Energy Procedia, vol. 50, pp. 559-566, 2014.

[28] Z. Khuzwayo and E. M. N. Chirwa, "Analysis of catalyst photo-oxidation selectivity in the degradation of polyorganochlorinated pollutants in batch systems using UV and 
$\mathrm{UV} / \mathrm{TiO}_{2}$," South African Journal of Chemical Engineering, vol. 23, pp. 17-25, 2017.

[29] R.-Y. Horng, C. Huang, M.-C. Chang, H. Shao, B.-L. Shiau, and Y.-J. Hu, "Application of $\mathrm{TiO}_{2}$ photocatalytic oxidation and non-woven membrane filtration hybrid system for degradation of 4-chlorophenol," Desalination, vol. 245, no. $1-3$, pp. 169-182, 2009

[30] M. Muruganandham and M. Swaminathan, "Photochemical oxidation of reactive azo dye with UV $-\mathrm{H}_{2} \mathrm{O}_{2}$ process," Dyes and Pigments, vol. 62, no. 3, pp. 269-275, 2004.

[31] S. Haji, B. Benstaali, and N. Al-Bastaki, "Degradation of methyl orange by $\mathrm{UV} / \mathrm{H}_{2} \mathrm{O}_{2}$ advanced oxidation process," Chemical Engineering Journal, vol. 168, no. 1, pp. 134-139, 2011.

[32] R. A. R. Monteiro, C. Rodrigues-Silva, F. V. S. Lopes, A. M. T. Silva, R. A. R. Boaventura, and V. J. P. Vilar, "Evaluation of a solar/UV annular pilot scale reactor for $24 \mathrm{~h}$ continuous photocatalytic oxidation of $n$-decane," Chemical Engineering Journal, vol. 280, pp. 409-416, 2015.

[33] A. H. Jawad, N. S. A. Mubarak, M. A. M. Ishak, K. Ismail, and W. I. Nawawi, "Kinetics of photocatalytic decolourization of cationic dye using porous $\mathrm{TiO}_{2}$ film," Journal of Taibah University for Science, vol. 10, no. 3, pp. 352-362, 2016. 


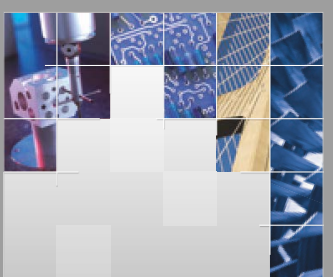

\section{Enfincering}
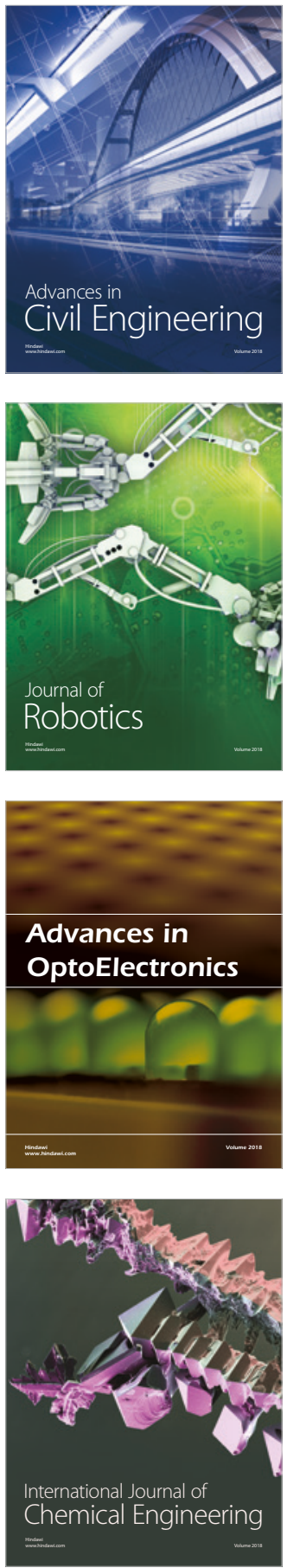

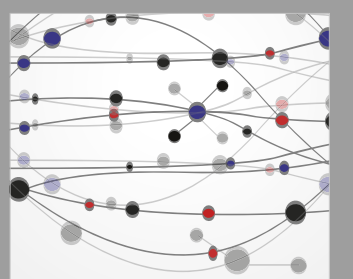

\section{Rotating \\ Machinery}

The Scientific World Journal

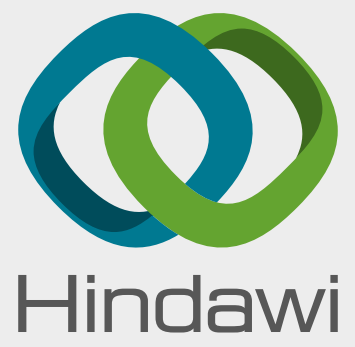

Submit your manuscripts at

www.hindawi.com
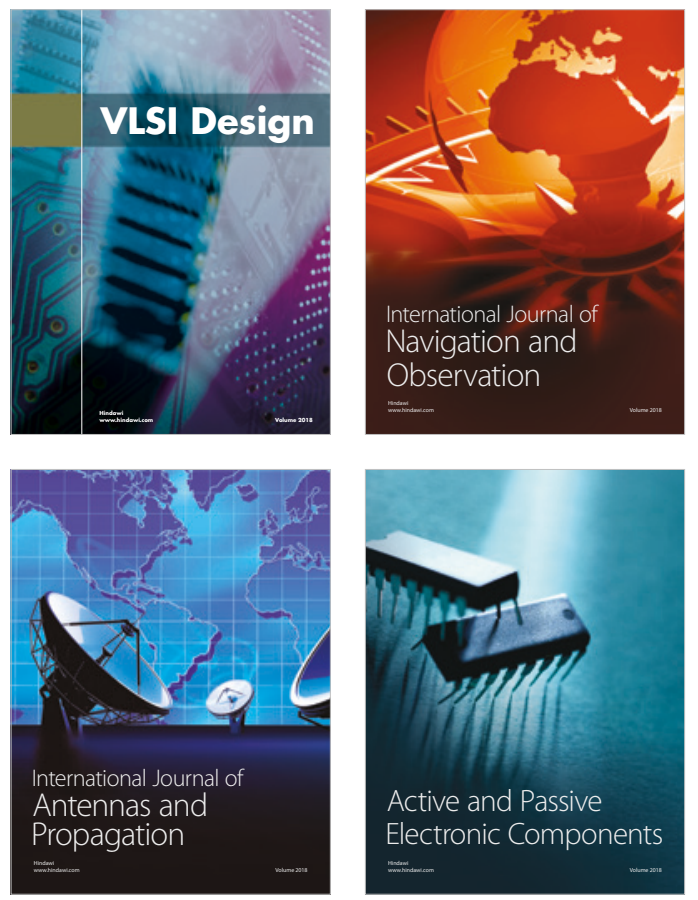
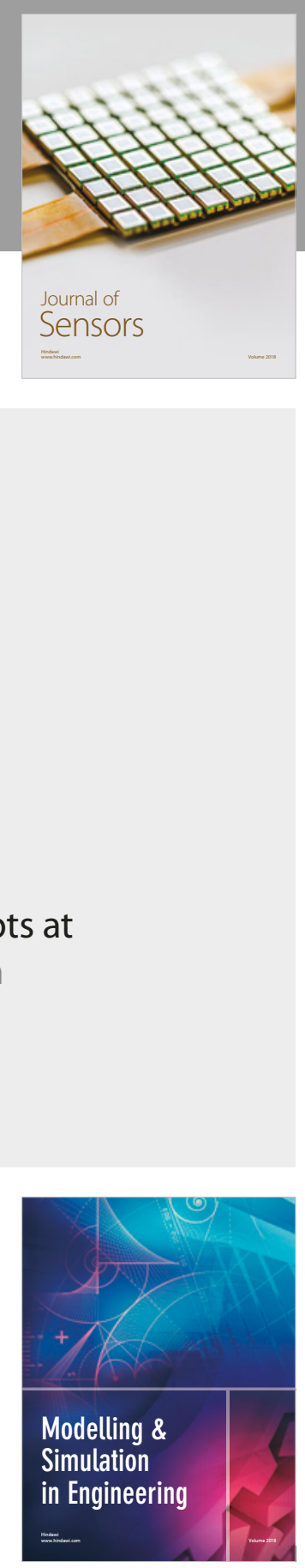

\section{Advances \\ Multimedia}
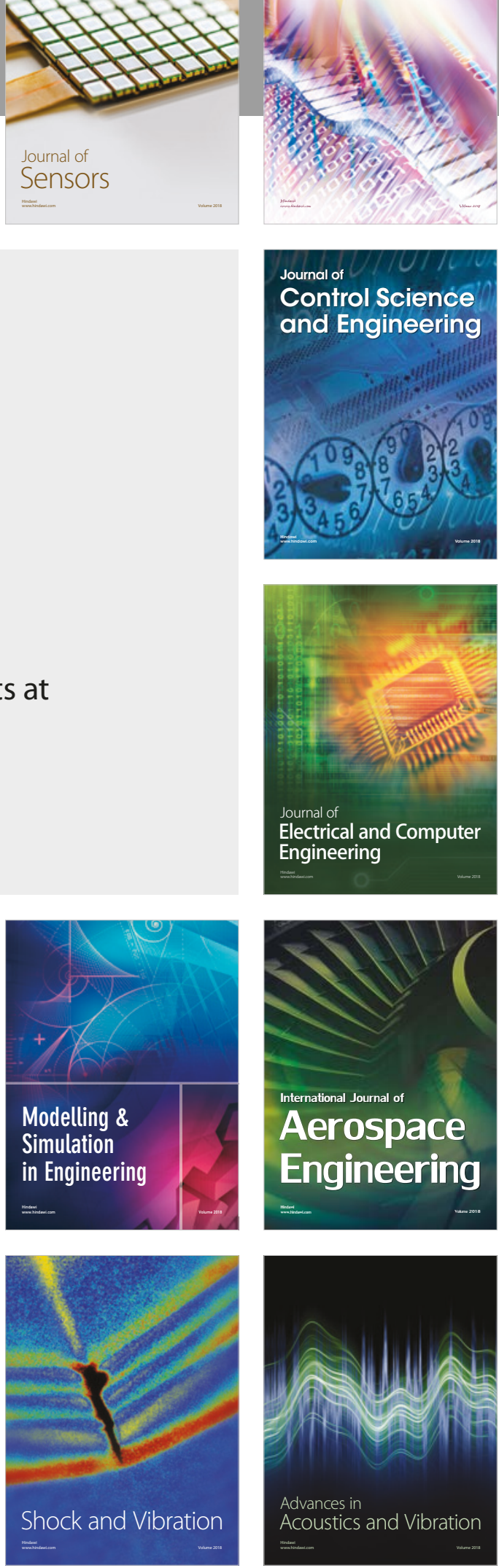